\title{
The Analysis of the Changes of Phonetics and Vocabulary in English
}

\author{
Kong Li \\ Lyceum of the Philippines University-Batangas City \\ 979185156@qq.com
}

\begin{abstract}
Keywords: English linguistics; Language; Vocabulary; Development history; Change in phonetics
\end{abstract}
\begin{abstract}
With the rapid development of information globalization, English has become an international language, and the study of English linguistics has already started as early as during the Renaissance, especially in Shakespeare's drama literature, the giants of English literature makes English language pronunciation, vocabulary usage, and structure have great progress. After the second world war, English was separated from the literary drama and became the lingua franca of international diplomats, gradually developing into a complete English linguistic system. Then, during the colonial period of the British empire, the English language was widely expanded and became the universal voice. By understanding the development of English linguistics, this paper makes a brief analysis of the changes of English phonetics and vocabulary.

Currently in international communication, English is the main foreign language, so many countries in the world speak English as their second language, and now we use English, has one thousand five hundred years of development, from the original Old English, combined with the requirements of The Times, slowly after a lot of time evolution of the modern English, in the process of the evolution of English, English pronunciation and vocabulary is the most obvious. The study of English language in the world has a long history, from the perspective of English language study English in pronunciation and vocabulary development and changes, can accurately grasp the standard English pronunciation and vocabulary, so as to better learning English.
\end{abstract}

\section{The Evolution of English Linguistics}

In the 17th century European Renaissance period, the famous drama writer Shakespeare created the rich connotation of "wind" Shakespeare's language, in his drama creation, because of the language and literature for the repeated carve, greatly enriched the English language pronunciation, vocabulary and structure, English language development to a new stage. Until the mid 17th century, English literature appeared another only in Shakespeare's famous poet John Milton, his creation epic "paradise lost" and "paradise regained", the poetic drama the hughes, content vast and beautiful language, have greatly enriched the connotation of the English literature, and also for the development of the English language has played a vital role. From the beginning of the 19th century, the researchers of language and linguistics attaches great importance to social relations, to further expand the influence of the worldwide English linguistics, linguists put forward especially Poland will be divided into pure linguistics and applied linguistics. After the second world war, English emerged from the literary drama and became international.

Foreign language, and gradually develop into a complete system of English language, then because of the British empire colonial period, the British economy is a big influence for the world, many countries in the world speak English as a must learn a second language, makes English language further expansion, gradually become an international language.

\section{The Phonetic Change of English Linguistics}

As people in different parts of the world have different environments and different pronunciation habits, with the continuous development of society, English language and phonetics have changed constantly with the changes of The Times. Therefore, in English linguistics, the change of English phonetics is the most obvious, and the development and change of English phonetic phonetics also run through the whole development of English linguistics. 
The Change of Vowel in English Phonetics. With the development of English linguistics in the Renaissance and the expansion of English application environment, middle English linguistics gradually developed into modern English linguistics. One of the English linguistics vowel change is most obvious, vowel pronunciation tongue raised, and is also reduced a lot, especially after the vowel and unit has had the obvious change, only the double vowel pronunciation method is relatively stable. For example, the vowel of a vowel [a] is moved forward and gradually improved; When the vowel [e] is pronounced, the tongue moves forward, and the opening degree becomes smaller and more similar to [I]. [I] the pronunciation is mainly supplemented by the corresponding phoneme, similar to [ai], [ei]. The [ou] pronunciation of diphthongs also changes to [au].

Changes in Pronunciation in Modern English Pronunciation. There are several reasons for the change of pronunciation in modern English linguistics: the absence of speech, mainly the loss of phonemes, and the two aspects of the phoneme. Because in some English words, some vowels are attached to another vowel, and the vowels are easily omitted. Or the two consonants are in polysyllabic, especially the vowels in the two consonants are often omitted when they are pronounced. Double vowel in pronunciation, originally is stressed in front of the back light reading, but people in the actual pronunciation, often omit the second vowel, so double vowel or three vowel is often read as unit, has gradually caused the lack of voice. In addition, it is the addition of vowels or consonants into words. The two consecutive pronunciation positions are interchanged. [I :] the position of the tongue is moved backwards, and the opening level is a little larger than before. [u] the pronunciation has now been replaced by [v]. [e] the tongue position was lowered by the pronunciation. The process of three vowel sliding is reduced and so on.

\section{Vocabulary Changes in English Linguistics}

Vocabulary is the most active part of language, it with the development of social economy, politics and culture, there will be some changes even appeared some new words, and the development of the English language change, the evolution of words as well as the important one of the main factors.

The Appearance of Synthetic Words. In English linguistics, the combination of English words with the concept of each other is called synthetic words. Synthetic words do not change the way words are spelled, but the meaning of words changes, not even the words that make up the words themselves. For example: anyway, blackboard, blending, bookshop, compounding, classmate, handsome, the output, penfriend, schoolmate, seafood, without, watermelon, etc.

The Appearance of Austerity Words. In English linguistics, the extraction of a part of some words to form a new vocabulary is called austerity. For example, the word "breakfast" is a combination of "break" and "fast"; The word docusoap is recombined by a portion of document and soap. The word "smog" is a recombination of smoke and fog.

The Appearance of Euphemism. Due to the historical and cultural and living environment of each country is different, there are different provisions in custom, so many countries or there'll be some taboos on is a man in a language, but in social activities sometimes encounter something must speak out, so people often use euphemism other words to replace taboo words, euphemism method is common vocabulary in English linguistics means and methods of metaphor. For example, when referring to death, English usually does not use "death" directly, but euphemistically USES the metaphor of "sleep forever" to express itself. In the case of US President Nixon's election scandal, it is often used as a euphemism for "watergate thing".

The Emergence of lexical Innovation. With the progress of social economy, make people has given rise to a lot of new ideas, new things, and therefore produced a large number of new words, words of updated to better serve the needs of people's production and life, this also is in the English language vocabulary updating a very important reason. Especially in recent years, there are lots of English new words, such as: facebook (facebook), Earth Day (Earth), visual pollution, visual pollution), anti - pollutionist (pollution), environment expert (experts) environmental protection, cultural gap (cultural gap), etc.

Use of Acronyms. In the English language, will be abbreviated as new some longer English vocabulary words, acronyms and it while maintaining the original word meaning unchanged, let the 
spelling of words become more simple, use the acronym in English linguistics, can be more convenient memory long English vocabulary. For example, the abbreviation for Asymmetrical Digital Subscriber Line is ADSL. The Central Processing Unit(CPU) stands for CPU; The abbreviation for Global Position System(GPS) is GPS; The International Organization for Standardization(ISO) stands for ISO. Automatic Teller Machine is abbreviated to ATM. There are a lot of acronyms like this, which can be used to express the meaning of a word in concise abbreviations, so that people can learn English more effectively.

Emotional Changes. An important cause of the change of the English language in vocabulary is of English words, some changes have taken place in emotional color in actual social life, people for some things or the expression of emotion is with emotion, said the same words in different occasions the meaning will be different. For example, the common word "shrewd" in Old English is meant to be dishonest and malicious, but now the meaning is clever and clever, and the former negative words have become neutral words. "Awfully" used to mean something terrible, but now it is more used to express good meaning. In our daily spoken English, "awfully good" is used to mean excellent. And some vocabulary itself with two sides meaning, but if is often used to represent the meaning of bad, it is a good meaning will gradually disappear, for example, the word "gay" and had the meaning of happy, happy, but now people more is used to represent gay.

Changes in Meaning. In English linguistics, as time goes on, some English words will expand and shrink. The word meaning expands to mean the meaning of the word itself. For example, "Lady "originally means the hostess, now refers to any woman; The word "handsome" used to mean that men are handsome, but now they mean a lot. The reduction of meaning refers to the narrowing of the meaning of words. For example, "meat" originally refers to all food, and now it only represents the meat of animals. "Hangar" used to refer to all the booths, now it refers to the hangar. "Deer" used to refer to wild animals. Now it refers specifically to "deer". This type of vocabulary has a lot to do, so the vocabulary of English linguistics has changed a lot with time.

\section{Conclusion}

To sum up, English linguistics research from 17th century Europe had already started during the Renaissance, the famous writer Shakespeare's drama literature got unprecedented progress makes English linguistics, greatly enriched the English language pronunciation and vocabulary; With after the second world war, because the British economy had a great influence on the world at that time, many countries regard English as their second language, also let English become the international language, after one thousand five hundred years of development, from the original Old English, for the development of modern English, great changes have taken place in the English language, the most obvious one is the change of pronunciation and vocabulary of English. In this paper, the English language pronunciation and vocabulary changes are briefly analyzed, and the changes of the English linguistics pronunciation and vocabulary, is conducive to our better explore the law of development of human language, also can let people better learning English.

\section{References}

[1] zhang min. Analysis of the changes in English language phonetics and vocabulary [J]. Modern communication,2014,13(11):21-21.

[2] Chen weiyi. A brief discussion on the changes of English language phonetics and vocabulary [J]. Test journal,2012,26(86):74-74.

[3] li chao. On the changes of English language phonetics and vocabulary [J]. Overseas English (top),2015,10(8):201-202.

[4] yao zhang. Changes in English phonetics and vocabulary [J]. Journal of education college, 2013,35(6):40-41.

[5] geng weifeng. A study on the change of speech and vocabulary in English and Chinese [J]. South. The wind, 2014, 21 (33) : 26-26. 
[6] ma wenli. Analysis of the mystery of English success from the perspective of linguistics [J]. Journal of hunan university (social science edition),2000,14(4):82-85.

[7] segment baojing. A brief analysis on the factors and history of the development of English linguistics $[\mathrm{J}]$. Journal of shandong commercial vocational and technical college,2014,14(6):91-93. 